\title{
The pan-histone deacetylase inhibitor LBH589 (panobinostat) alters the invasive breast cancer cell phenotype
}

\author{
NICOLETTA FORTUNATI ${ }^{1}$, FRANCESCA MARANO $^{2}$, ANDREA BANDINO $^{3}$, ROBERTO FRAIRIA $^{2}$, \\ MARIA GRAZIELLA CATALANO ${ }^{2}$ and GIUSEPPE BOCCUZZI ${ }^{2}$ \\ ${ }^{1}$ Oncological Endocrinology, AO Città della Salute e della Scienza di Torino; ${ }^{2}$ Department of Medical Sciences, \\ University of Turin, I-10126 Torino; ${ }^{3}$ Department of Oncology, Biochemistry Section, \\ University of Turin, I-10100 Torino, Italy
}

Received September 10, 2013; Accepted October 22, 2013

DOI: $10.3892 /$ ijo.2013.2218

\begin{abstract}
Triple-negative breast cancer (TNBC) is a very aggressive type of tumour and its aggressiveness is linked to E-cadherin downregulation. In estrogen-sensitive breast cancer, high levels of E-cadherin fit with high levels of ER $\alpha$ and MTA3 (a component of the transcription Mi-2/NuRD complex with intrinsic DAC activity). In TNBC the E-cadherin downregulation could be due to epigenetic silencing of the $C D H 1$ gene as well as to the lack of a fully functioning ER $\alpha$-activated pathway. We report that the pan-histone deacetylase inhibitor LBH589, a potent anti-proliferative agent, induced E-cadherin expression on cell membranes of MDA-MB-231 cells (TNBC), determining a reduction of cell invasion and migration. Even though E-cadherin expression in breast cancer is also regulated by estradiol and the ER $\alpha /$ MTA3/Snail/Slug pathway, LBH589 is able to increase E-cadherin without affecting the estrogen pathway. In fact, no expression of ER $\alpha$, PR and Fox A1 was observed in MDA-MB-231 cells before and after LBH589 treatment; furthermore, the drug caused an increase in Snail and Slug expression with a concomitant reduction of MTA3 levels. Taking into consideration its anti-proliferative and anti-invasive properties, we suggest the use of LBH589 in aggressive breast cancer refractory to hormonal therapy.
\end{abstract}

\section{Introduction}

Breast cancer, the most common cancer in women all over the world (1), is generally managed with success thank to available treatments (2). Regrettably, resistance to conventional therapy and increasing in metastatic and aggressive disease are emerging problems $(3,4)$. A particular aggressive subtype

Correspondence to: Dr Nicoletta Fortunati, Oncological Endocrinology, AO Città della Salute e della Scienza di Torino, Via Genova 3, I-10126 Torino, Italy

E-mail: nfortunati@cittadellasalute.to.it

Key words: E-cadherin, estrogen receptor, DCI, triple-negative breast cancer, epigenetic of breast cancer is the triple-negative breast cancer (TNBC) that is defined by the absence of ER, PR and Her2/neu $(5,6)$. TNBC generally occurs more frequently in younger women, frequently presents early metastatic spread and has poor overall prognosis $(7,8)$.

In breast cancer, as well as in other tumour types, epigenetic modifications are considered a crucial mechanism involved in cancer growth, dedifferentiation and aggressiveness; indeed, epigenetic deregulation can alter a number of molecular pathways involved in the control of cell function. Epigenetic drugs, able to restore normal epigenome in cancer cells, are under extensive pharmacological research (9). In breast cancer, histone acetylation state is considered of great importance. Histone acetylation and deacetylation, controlled by the enzymes histone acetyltransferases (HATs) and histone deacetylases (HDACs), affect chromatin conformation and, therefore, gene transcription, DNA repair and replication, and cell cycle checkpoints (10). Altered expression of HDACs has been reported in breast cancer by several authors $(11,12)$. Therefore, HDAC inhibitors (DCI) are considered valuable therapeutic tools and have been under extensive evaluation. DCI vorinostat (13), for example, in association with paclitaxel and bevacizumab induced a partial or complete response in $>50 \%$ of patients with metastatic breast cancer. The antiproliferative and re-differentiating effect of several DCI was reported in vitro by a number of laboratories (14-17). In recent years, the pan-deacetylase inhibitor panobinostat (LBH589) has been taken into consideration. Our laboratory demonstrated for the first time that LBH589 in nanomolar concentration is a potent antiproliferative agent in ER-positive and -negative breast cancer cells, and that its anticancer activity is sustained by $\mathrm{H} 4$ histone acetylation (18).

It is so well known that ER $\alpha$ is the hallmark of breast cancer estrogen sensitivity and good response to tamoxifen therapy (19) and that it can be lost during disease progression, giving rise to hormone-independent and aggressive phenotype (20). Epigenetic deregulation has also been considered one of the possible causes of ER $\alpha$ loss in breast cancer (e.g., histone tail deacetylation and methylation or methylation of the $\mathrm{CpG}$ islands in the ER promoter) (21). Hence, DCI were exhaustively studied also for their ability to restore ER $\alpha$ and its pathway in ER-negative breast cancer cells. VPA, for 
Table I. Primers for real-time PCR.

\begin{tabular}{|c|c|c|}
\hline \multirow[t]{2}{*}{ CDH1 } & Sense: & 5'-TTGAAAGAGAAACAGGATGGCTG-3' \\
\hline & Antisense: & 5'-TCATTCTGATCGGTTACCGTGAT-3' \\
\hline \multirow[t]{2}{*}{$\mathrm{ER} \alpha$} & Sense: & 5'-TGT GTC CAG CCA CCA ACC AG-3' \\
\hline & Antisense: & 5'-TTC AAC ATT CTC CCT CCT CTT CGG-3' \\
\hline \multirow[t]{2}{*}{ PR } & Sense: & 5'-GCA TCA GGC TGT CAT TAT GGT GTC-3' \\
\hline & Antisense: & 5'-CAT AAG TAG TTG TGC TGC CCT TCC-3' \\
\hline \multirow[t]{2}{*}{ FoxA1 } & Sense: & 5'-GGG TGG CTCCAG GAT GTT AGG-3' \\
\hline & Antisense: & 5'-GGG TCA TGT TGC CGC TCG TAG-3' \\
\hline \multirow[t]{2}{*}{ MTA3 } & Sense: & 5'-GTCGGAGATTATGTCTACTTTGAG-3' \\
\hline & Antisense: & 5'-CAGTCTTGTTGAGTTCTTCTATCC-3' \\
\hline \multirow[t]{2}{*}{ SNAIL } & Sense: & 5'-CCTGCGTCTGCGGAACCTG-3' \\
\hline & Antisense: & 5'-GGAGCGGTCAGCGAAGGC-3' \\
\hline \multirow[t]{2}{*}{ SLUG } & Sense: & 5'-AAACTACAGCGAACTGGACACAC-3' \\
\hline & Antisense: & 5'-GTGGTATGACAGGCATGGAGTAAC-3' \\
\hline \multirow[t]{2}{*}{$\beta-\mathrm{ACT}$} & Sense: & 5'-GCG AGA AGA TGA CCC AGA TC- 3' \\
\hline & Antisense: & 5'-GGA TAG CAC AGC CTG GAT AG-3' \\
\hline \multirow[t]{2}{*}{$\beta 2$-microglobulin } & Sense: & 5'-AGA TGA GTA TGC CTG CCG TGT G-3' \\
\hline & Antisense: & 5'-TCA ACC CTC CAT GAT GCT GCT TAC-3' \\
\hline \multirow[t]{2}{*}{ L13A } & Sense: & 5'-GCA AGC GGA TGA ACA CCA ACC-3' \\
\hline & Antisense: & 5'-TTG AGG GCA GCA GGA ACC AC-3' \\
\hline
\end{tabular}

example, was demonstrated by us (16) and by other authors (14) to restore estrogen and, thus, antiestrogen sensitivity in MDA-MB-231 cells considered a good model of TNBC; LBH589 was shown either to induce ER $\alpha$ in MDA-MB-231 cells (22), or not to have any detectable effect $(23,24)$.

Estradiol sensitivity is also strictly linked to aggressiveness of breast cancer cells. Aggressive breast tumours are characterized by E-cadherin downregulation that switches on the phenomenon called epithelial-to-mesenchimal transition (EMT), the corner stone of tumour spreading and metastasis (25). E-cadherin downregulation is mainly due to epigenetic alterations of $C D H 1$ gene promoter $(26,27)$ or by epigenetic controlled overexpression of several E-cadherin transcriptional repressors, such as Snail/SNAI1, Slug/SNAI2, SIP1/ ZEB2 or Twist (28-32).

In breast cancer, estradiol $\left(\mathrm{E}_{2}\right) / \mathrm{ER} \alpha$ and MTA3/Snail/ E-cadherin signalling pathways are intimately linked (33). Estradiol-activated ER $\alpha$ induces MTA3, a member of the histone deacetylase Mi-2/NuRD macro-complex, that downregulates Snail, upregulating E-cadherin (34). The absence of estrogen receptor or MTA3 leads to aberrant expression of the transcriptional repressor Snail and consequent inhibition of E-cadherin (30).

E-cadherin and its regulators are considered attractive therapeutic targets, in order to inactivate cell invasion and metastasis.

The aim of the present study was to evaluate the effect of the pan-deacetylase inhibitor panobinostat (LBH589) on expression and function of ER $\alpha$ and its cognate proteins PR (progesterone receptor) and FoxA1 (forkhead box A1), and of E-cadherin and its repressors Snail and Slug, in TNBC MDA-MB-231 cells.

\section{Materials and methods}

Cell lines and reagents. Triple-negative breast cancer cell line MDA-MB-231 and estrogen receptor-positive MCF-7 cells were purchased from ECACC (Salisbury, UK), which certifies the origin and identity of the cells. Moreover, none of the cell lines are included in the database of cross-contaminated or misidentified cell lines (http://www.hpacultures.org.uk/ services/celllineidentityverification/misidentifiedcelllines.jsp). Cells were routinely maintained at $37^{\circ} \mathrm{C}$, in $5 \% \mathrm{CO}_{2}$ and 95\% humidity, in RPMI-1640 (Sigma, St. Louis, MO, USA) with $100 \mathrm{IU} / \mathrm{ml}$ penicillin and $100 \mu \mathrm{g} / \mathrm{ml}$ streptomycin added, supplemented with $10 \%$ heat-inactivated FCS (Euroclone, Wetherby, UK). LBH589 was provided by Novartis Pharma AG (Basel, Switzerland), prepared as a $5 \mathrm{mM}$ stock solution in DMSO and stored at $-20^{\circ} \mathrm{C}$.

Gene expression: evaluation with real-time PCR. Cells $\left(1 \times 10^{6}\right)$ were seeded in $75-\mathrm{cm}^{2}$ flasks and treated with LBH589 (5-50 nM). Total RNA was extracted using TRIzol reagent (Invitrogen Ltd., Paisley, UK), as previously described. DNase I was added to remove remaining genomic DNA. Total RNA $(1 \mu \mathrm{g})$ was reverse-transcribed with iScript cDNA Synthesis 
kit (Bio-Rad Laboratories, Inc.), following the manufacturer's protocol.

Primers (Table I) were designed using Beacon Designer 5.0 software according to parameters outlined in the Bio-Rad iCycler manual. Specificity of primers was confirmed by BLAST analysis. Real-time PCR was performed using a Bio-Rad iQ iCycler Detection system (Bio-Rad Laboratories, Inc.) with SYBR green fluorophore. Reactions were performed in a total volume of $25 \mu \mathrm{l}$, including $12.5 \mu \mathrm{l}$ IQ SYBR Green Supermix (Bio-Rad Laboratories, Inc.), $1 \mu \mathrm{l}$ of each primer at $10 \mu \mathrm{M}$ concentration, and $5 \mu \mathrm{l}$ of the previously reversetranscribed cDNA template. Protocol for primer set was optimized using seven serial $5 \mathrm{X}$ dilutions of template cDNA obtained from cells in basal conditions.

The protocol used is as follows: denaturation $\left(95^{\circ} \mathrm{C}\right.$ for 5 min), amplification repeated 40 times $\left(95^{\circ} \mathrm{C}\right.$ for $15 \mathrm{sec}, 60^{\circ} \mathrm{C}$ for $1 \mathrm{~min}$ ). A melting curve analysis was performed following every run to ensure a single amplified product for every reaction. All reactions were carried out at least three times for each sample. Every gene expression level was normalized on the expression level of three house-keeping genes ( $\beta$-actin, L13A, $\beta$-2-microglobulin).

Immunoblotting. Sub-confluent breast cancer cells were treated with LBH589 (25 $\mathrm{nM})$ for $24 \mathrm{~h}$ and then they were harvested and lysed in the presence of lysis buffer $(0.5 \%$ Triton $\mathrm{X}-100$, $2.5 \mathrm{mM}$ EGTA, $5 \mathrm{mM} \mathrm{MgCl}_{2}, 50 \mathrm{mM} \mathrm{NaH}_{2} \mathrm{PO}_{4}$ ) for $2 \mathrm{~min}$ on ice. Soluble cytosolic fraction was recovered and stored at $-80^{\circ} \mathrm{C}$. The insoluble membrane fraction was dissolved in SDS sample buffer (TrizmaBase 0.2 M, glycerol 50\%, SDS 10\%), recovered and stored at $-80^{\circ} \mathrm{C}$.

SDS-PAGE was performed on gels, loading $30 \mu \mathrm{g}$ protein/ well. Separated proteins were electro-transferred onto PVDF membrane and probed with anti-E-cadherin antibody $(1: 1,000$ dilution, Sigma). PVDF membrane was then stripped and re-probed with an anti- $\alpha$-tubulin antibody (clone 6-11B-1, 1:2,000 dilution, Sigma) to check protein loading. Proteins were detected with Pierce Super Signal chemiluminescent substrate following the manufacturer's instructions. Bands were photographed and analyzed using Kodak 1D Image analysis software.

Immunofluorescence microscopy. Cells $\left(4 \times 10^{3}\right)$ were seeded in 96-well plates and treated with $25 \mathrm{nM} \mathrm{LBH} 589$ for $24 \mathrm{~h}$. After treatment, cells were fixed in PFA $1 \%$ and incubated with polyclonal anti-E-cadherin antibody (1:100 dilution, Sigma) at $4^{\circ} \mathrm{C}$ overnight. Then cells were washed with PBS containing $0.5 \%$ Triton and $0.05 \% \mathrm{NaN}_{3}$ followed by detection with antirabbit Cy3-conjugated secondary antibody (1:1,000 dilution, GE Healthcare Europe, $\mathrm{GmbH}$, Milan, Italy) in PBS plus $0.5 \%$ Triton and $0.05 \% \mathrm{NaN}_{3}$ for $2 \mathrm{~h}$. Nuclear staining was obtained by treating cells with Hoechst $33258(500 \mathrm{ng} / \mathrm{ml}$ in DMSO) in PBS. Cells were washed twice with distilled water and mounted with $50 \%$ glycerol-PBS media.

Scratch wound assay. Cells $\left(2 \times 10^{5}\right)$ were seeded in 6-well plates. Cells were treated with $25 \mathrm{nM}$ LBH589 for $24 \mathrm{~h}$ and afterwards cell monolayer was gently wounded by scratching. The cells were washed twice with cooled PBS and incubated for further $24 \mathrm{~h}$ either in the absence or presence of $25 \mathrm{nM}$
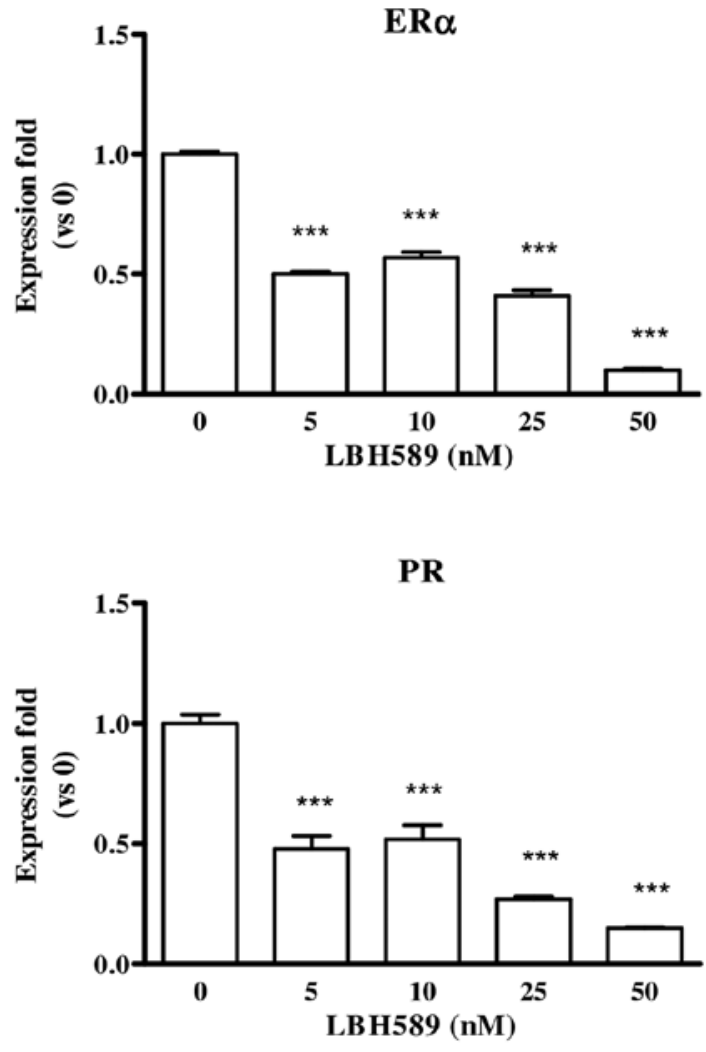

FoxA1

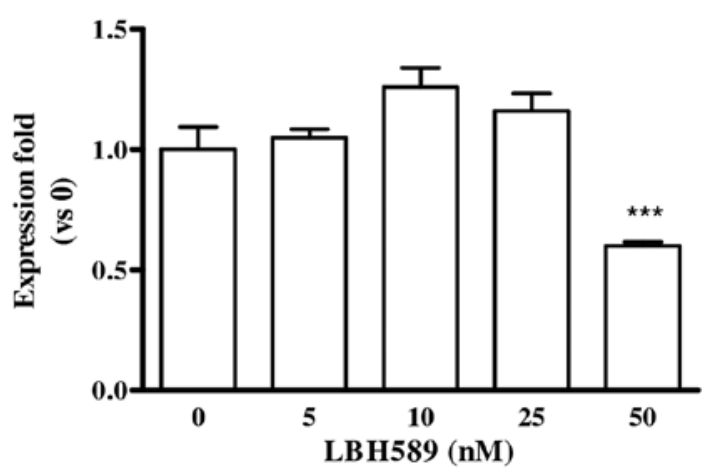

Figure 1. Effect of LBH589 on ER $\alpha, \mathrm{PR}$ and FoxA1 gene expression in MCF-7 cells. ER $\alpha$, PR and FoxA1 mRNA was evaluated in MCF-7 cells treated with increasing doses of LBH589 with real-time PCR. Results were normalized for three different housekeeping genes ( $\beta$-actin, $\beta 2$-microglobulin and L13A) and expressed as relative expression fold vs untreated controls (0). Results are expressed as the means $\pm \mathrm{SD} ; \mathrm{n}=3 ;{ }^{* * *} \mathrm{P}<0.001$. The evaluation was performed also in MDA-MB-231 cells; no expression of ER $\alpha, \mathrm{PR}$ and FoxA1 mRNA was detectable either in basal condition or after LBH589 treatment.

LBH589. For each wound, pictures were taken in the same field and the distance between the wound edges was analyzed using the Image J 1.42 software. For each condition, the percentage of the wound recovery in respect to the wound area at $0 \mathrm{~h}$, was calculated.

Invasion assay. Cells $\left(5 \times 10^{5}\right)$ were seeded in $75-\mathrm{cm}^{2}$ flasks and treated with LBH589 (25 nM). After $24 \mathrm{~h}, 2 \times 10^{5}$ cells were seeded in the BD BioCoat ${ }^{\mathrm{TM}}$ BD Matrigel ${ }^{\mathrm{TM}}$ invasion chamber (BD Biosciences Discovery Labware, Two Oak Park, Bedford, 
A

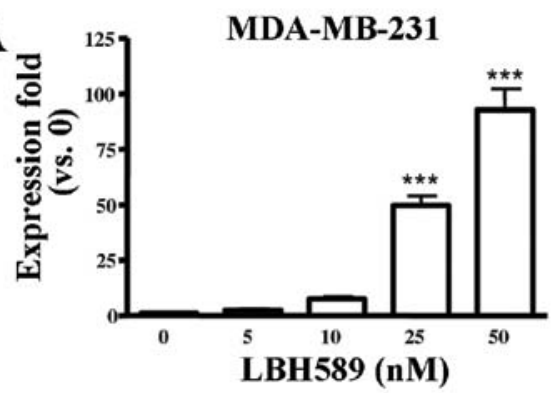

B
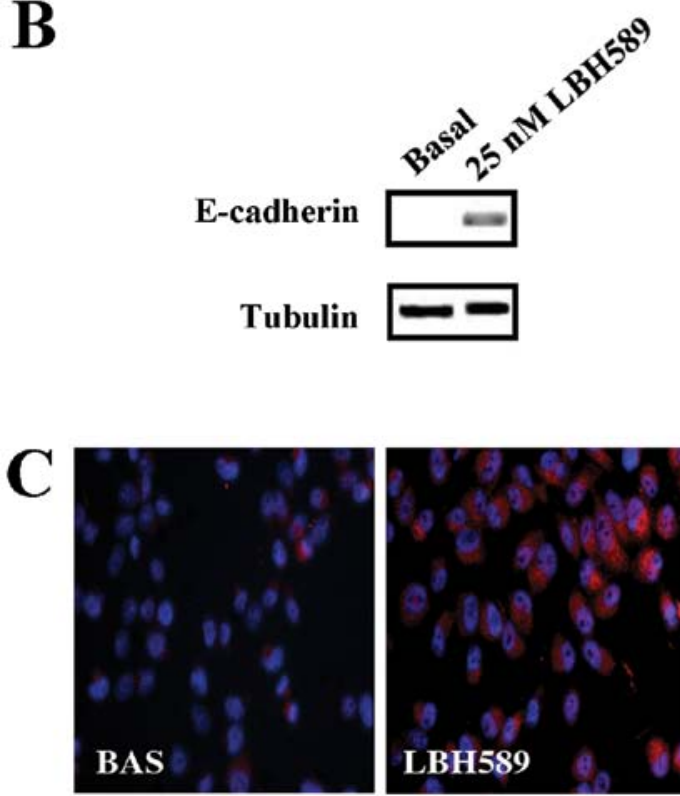
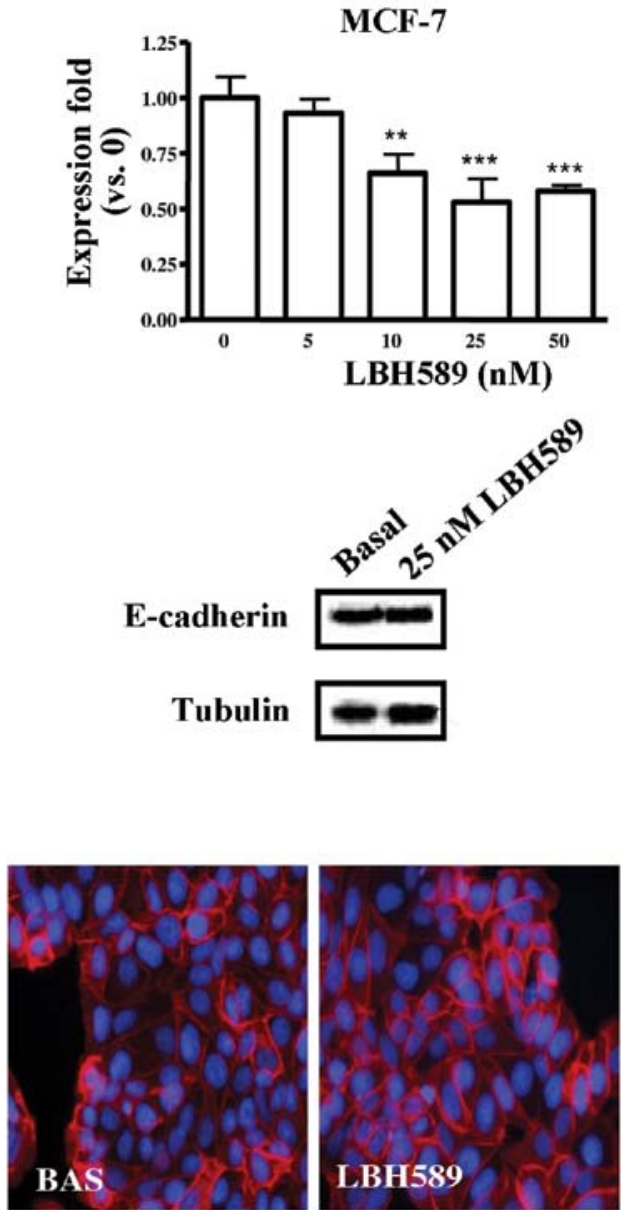

Figure 2. Effect of LBH589 on E-cadherin expression and localization. (A) E-cadherin mRNA was evaluated in MDA-MB-231 and MCF-7 cells with real-time PCR. Results were normalized for three different housekeeping genes ( $\beta$-actin, $\beta 2$-microglobulin and L13A) and expressed as relative expression fold vs untreated controls ( $0 \mathrm{nM}$ LBH589). Results are expressed as the means $\pm \mathrm{SD} ; \mathrm{n}=3 ;{ }^{* *} \mathrm{P}<0.01 ;{ }^{* * *} \mathrm{P}<0.001$. (B) Western blotting for E-cadherin was performed on membranes obtained from MDA-MB-231 and MCF-7 cells before and after treatment with $25 \mathrm{nM}$ LBH589. Equal loading and transfer were verified by re-probing the blot with anti-tubulin antibodies. The image shows a typical experiment. (C) E-cadherin protein localization in MDA-MB-231 and MCF-7 cells. Immunofluorescence for E-cadherin was performed on cells before and after 25 nM LBH589 treatment. Magnification, x400.

MA, USA) and stimulated with $25 \mathrm{nM} \mathrm{LBH589}$ for $24 \mathrm{~h}$. At completion, the lower surfaces of the membrane were fixed with methanol and stained with crystal violet solution, to point out cells that migrated across the Matrigel and invaded the inferior face of the membranes. The number of cells that had migrated to the basal side of the membrane was quantified by counting 12 independent fields under the microscope.

Luciferase assay. Cells $\left(2.5 \times 10^{5}\right)$ were seeded in 6-well plates. After $24 \mathrm{~h}$, cells were transfected with $1 \mu \mathrm{g}$ of pGL2BasicEcadK1 plasmid/well using Lipofectin reagent (Invitrogen Ltd.). The plasmid (Promega Italia, Milan, Italy) contains the human $C D H 1$ promoter sequences from -108 to +125 linked to the luciferase gene as reporter (17). After transient transfection, cells were treated with $25 \mathrm{nM} \mathrm{LBH} 589$ for $24 \mathrm{~h}$. Luciferase activity was assayed with the Luciferase assay system (Promega Corp., Madison, WI, USA).

Statistical analysis. Data are expressed throughout as the means $\pm \mathrm{SD}$, calculated from at least three different experiments. Comparison between groups was performed with analysis of variance (one-way ANOVA) and the threshold of significance was calculated with the Bonferroni test. Statistical significance was set at $\mathrm{P}<0.05$.

\section{Results}

LBH589 effect on ER $\alpha, P R$ and FoxA1. First of all, the effect of LBH589 on the expression of ER $\alpha$ and cognate PR (progesterone receptor) and FoxA1 (forkhead box A1) was studied. In estrogen-sensitive MCF-7 cells, LBH589 reduced the level of expression of all the three genes (Fig. 1), while MDA-MB-231 cells did not express any of the genes under study, neither in basal condition nor after LBH589 treatment.

LBH589 effect on E-cadherin expression. E-cadherin was not expressed in untreated MDA-MB-231 cells; LBH589 treatment increased E-cadherin gene expression, its effect being evident at doses $\geq 25 \mathrm{nM}$; a slight reduction of gene expression in E-cadherin positive MCF-7 cells was also observed (Fig. 2A). Western blotting for E-cadherin, reported in Fig. 2B, confirmed that increased gene expression resulted in the appearance of the protein in MDA-MB-231 cells; on the other hand, the reduction of E-cadherin gene expression 
MDA-MB-231

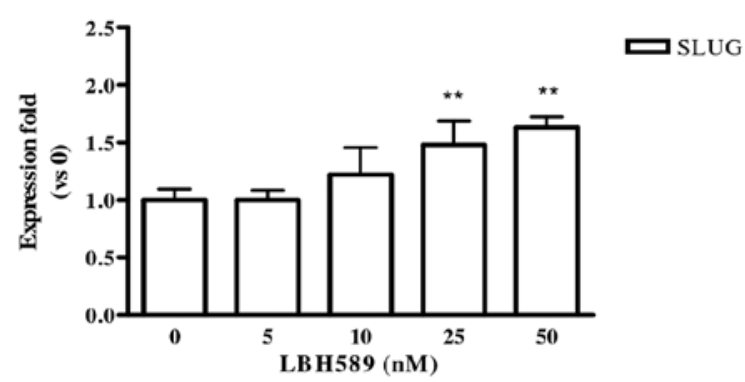

MDA-MB-231

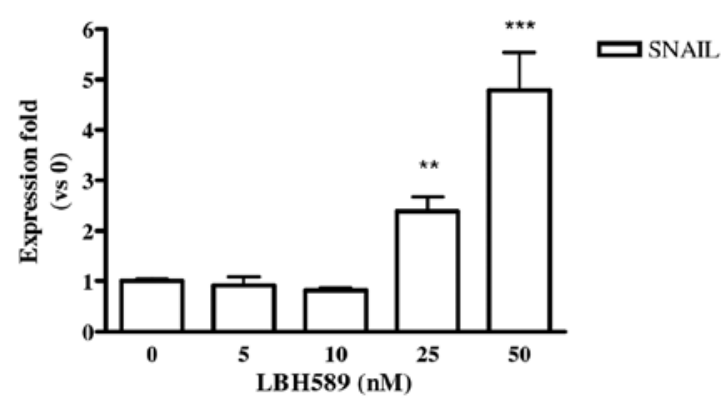

MDA-MB-231

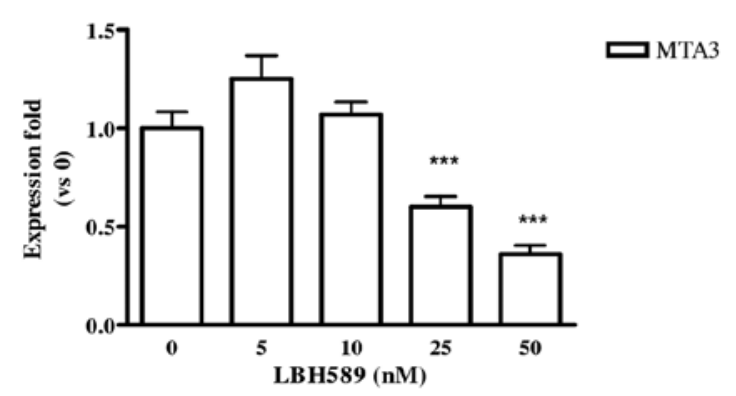

MCF-7

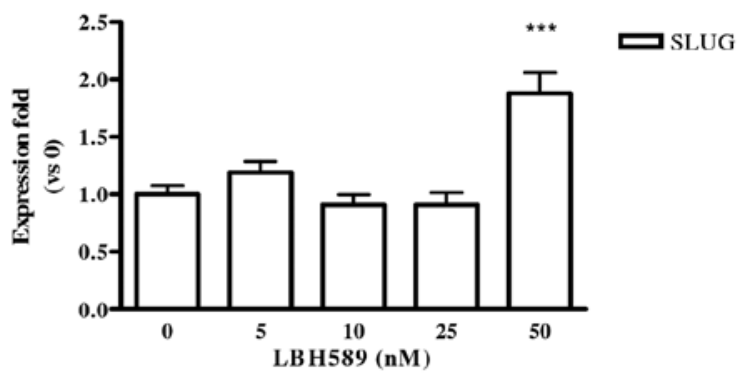

MCF-7

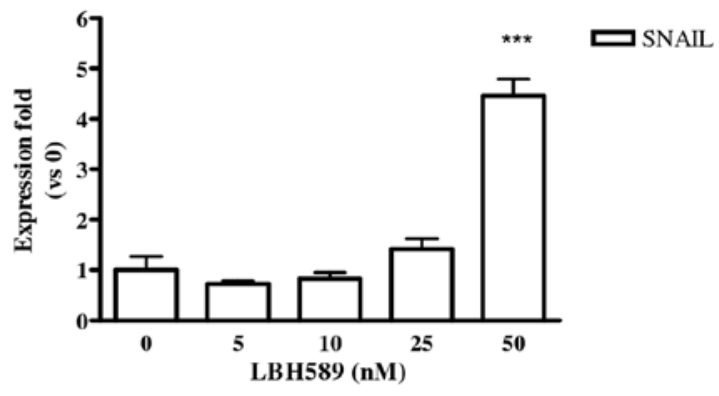

MCF-7

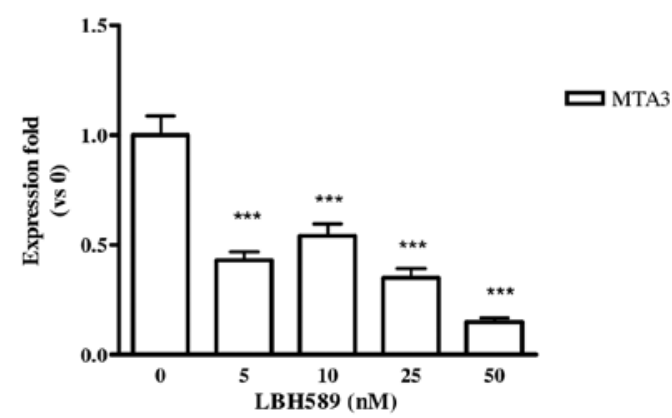

Figure 3. Effect of LBH589 on Snail, Slug and MTA3 gene expression. Snail, Slug and MTA3 mRNA was evaluated in MDA-MB-231 and MCF-7 cells treated with increasing doses of LBH589 $(5-50 \mathrm{nM})$ with real-time PCR. Results were normalized for three different housekeeping genes $(\beta$-actin, $\beta 2$-microglobulin and L13A) and expressed as relative expression fold vs untreated controls (0 nM LBH589). Results are expressed as the means \pm SD; $\mathrm{n}=3 ;{ }^{* * *} \mathrm{P}<0.01 ;{ }^{* * *} \mathrm{P}<0.001$.

observed in MCF-7 cells was not followed by a significant reduction of the protein level. LBH589 treatment determined also a correct expression of E-cadherin on the MDA-MB-231 surface (Fig. 2C).

LBH589 effect on Slug, Snail and MTA3. Both E-cadherin repressors, Slug and Snail, were evaluated. As reported in Fig. 3, the expression of Slug and Snail was significantly enhanced by LBH589 treatment in both cell lines. Lastly, the Mi-2/NuRD macro-complex member MTA3 was studied. We observed that LBH589 significantly reduced the level of expression of MTA3 in both cell lines (Fig. 3, last row).

LBH589 effect on cell migration and invasion. To determine whether LBH589 had a role in MDA-MB-231 cell migration, a scratch wound assay was carried out. As shown in Fig. 4, the migration of treated cells was significantly reduced with respect to untreated controls. After $24 \mathrm{~h}$, cells treated with $25 \mathrm{nM}$ LBH589 occupied only $15 \%$ of the wound compared to $33 \%$ occupation of untreated cells $(\mathrm{P}<0.001)$. Moreover, the role of LBH589 on the invasive potential of MDA-MB231 cells was assayed through the use of a transwell invasion chamber (Fig. 5). We observed that invasion of treated cells was markedly reduced compared with untreated cells after $24 \mathrm{~h}(\mathrm{P}<0.001)$. As reported also in Figs. 4 and 5, migration and invasion of MCF-7 cells were not affected by LBH589 treatment.

LBH589 effect on CDH1 promoter. To evaluate whether LBH589 directly acts on $C D H 1$ promoter inducing transcription, a luciferase assay using a construct containing $\mathrm{CDH}$ promoter was performed. We observed a significant increase in $\mathrm{CDH} 1$ promoter transcription level homogeneous with the increase of E-cadherin we reported above in MDA-MB-231 
MDA-MB-231
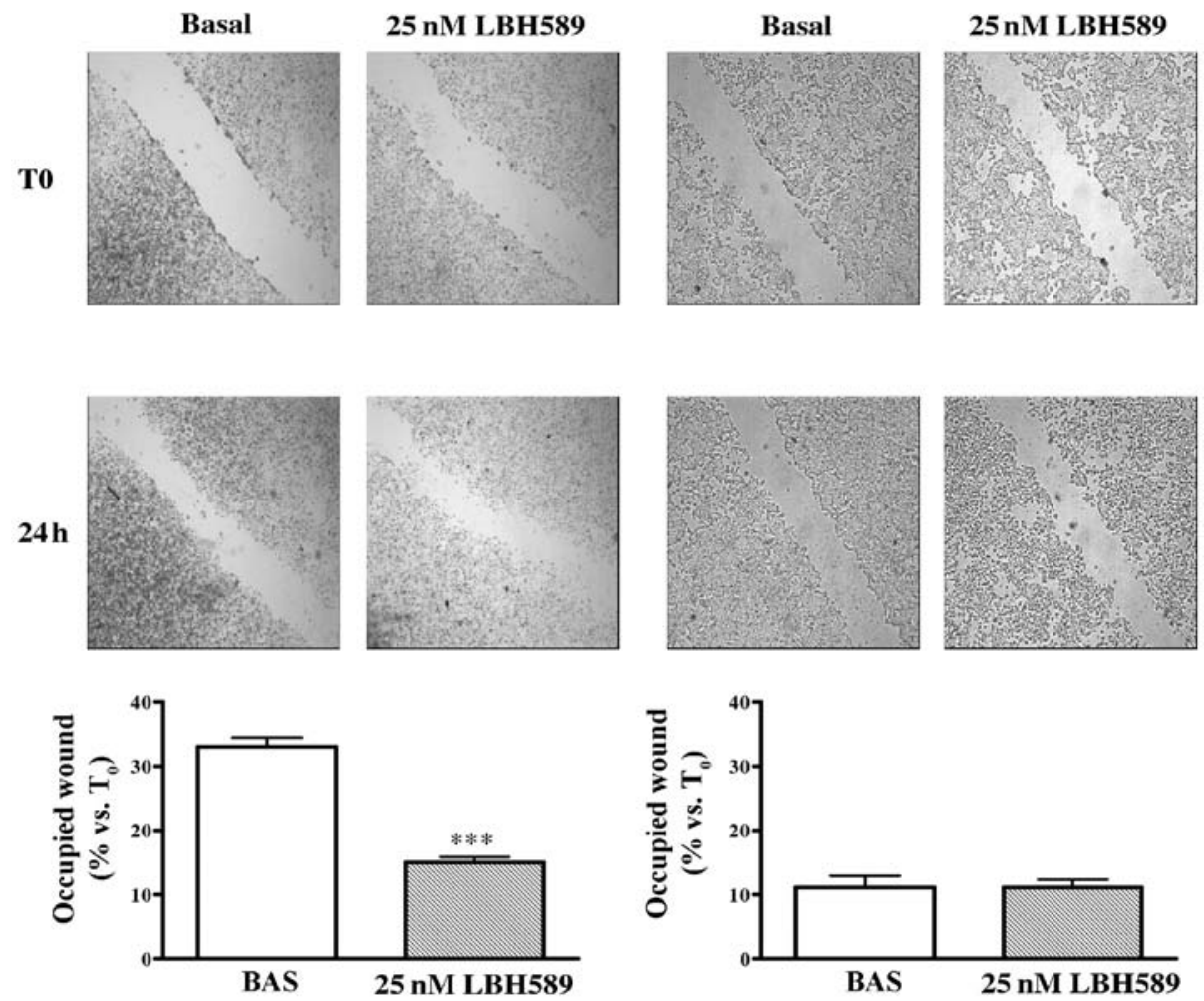
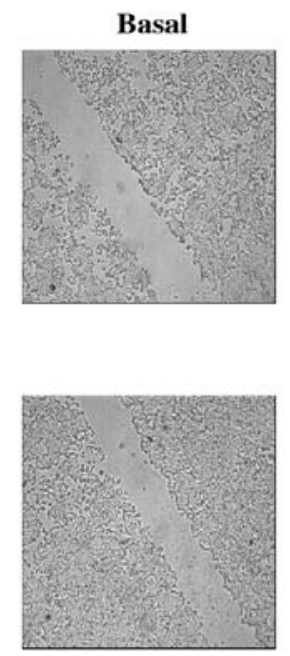

MCF-7

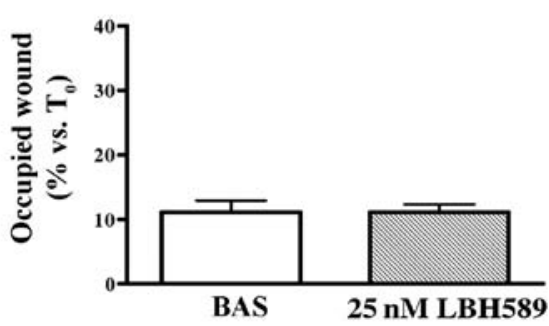

Figure 4. Effect of LBH589 on MDA-MB231 and MCF-7 cell invasion. Scratch wound assay was performed on cells before and after treatment with $25 \mathrm{nM}$ LBH589. A typical experiment is reported in the upper panels. Results, expressed as percent of occupied wound after $24 \mathrm{~h}$ with respect to T0, are reported in the lower panels; data are expressed as the mean $\pm \mathrm{SD} ; \mathrm{n}=3 ;{ }^{* * * *} \mathrm{P}<0.001$.

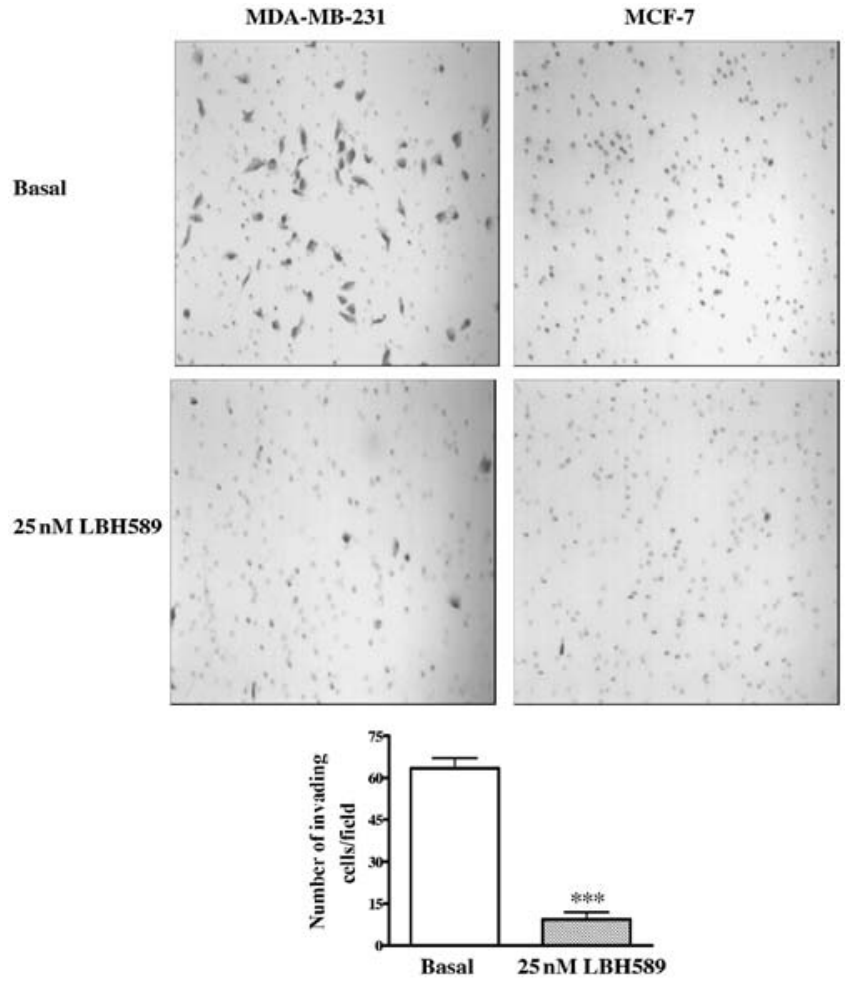

Figure 5. Effect of LBH589 on MDA-MB231 and MCF-7 cell migration. Matrigel invasion assay was performed on cells before and after treatment with $25 \mathrm{nM} \mathrm{LBH589.} \mathrm{A} \mathrm{typical} \mathrm{experiment} \mathrm{is} \mathrm{reported} \mathrm{in} \mathrm{the} \mathrm{upper} \mathrm{panels.}$ Results, expressed as number of invading cells/field, are reported in the lower panels; data are expressed as the mean $\pm \mathrm{SD} ; \mathrm{n}=3 ;{ }^{* * *} \mathrm{P}<0.001$. No significant migration of MCF-7 cells was observed in either condition. cells; the direct effect of LBH589 on $\mathrm{CDH} 1$ promoter was observed even in MCF-7 cells (Fig. 6).

\section{Discussion}

The pan-deacetylase inhibitor LBH589 is a powerful antitumour agent even at low nanomolar concentrations in a number of hematologic and solid tumours. It was, in addition, reported to induce re-expression of previously silenced genes modulating thus the behaviour of cancer cells (35-37).

The present report follows our previous observation in breast cancer cells where we observed a potent cytotoxic activity of LBH589 in both estrogen-sensitive and -insensitive cells (16). Our present data demonstrate that LBH589 induces E-cadherin gene expression in aggressive TNBC cells. E-cadherin gene expression resulted, furthermore, in the correct appearance of the cognate protein on MDA-MB-231 surface and, the re-expression of E-cadherin caused a clear modification of MDA-MB-231 cell behaviour. In fact, after LBH589 treatment, cell migration and invasive potential were greatly reduced.

Our previous observation on the anti-proliferative and pro-apoptotic effects of LBH589 in ER-negative breast cancer cells has been recently confirmed by other authors (38). The same authors reported that the most induced gene by LBH589 treatment in MDA-MB-231 cells is the $C D H 1$ gene that codes for E-cadherin, in total agreement with our observation on the increase of the $C D H 1$ gene promoter activity 

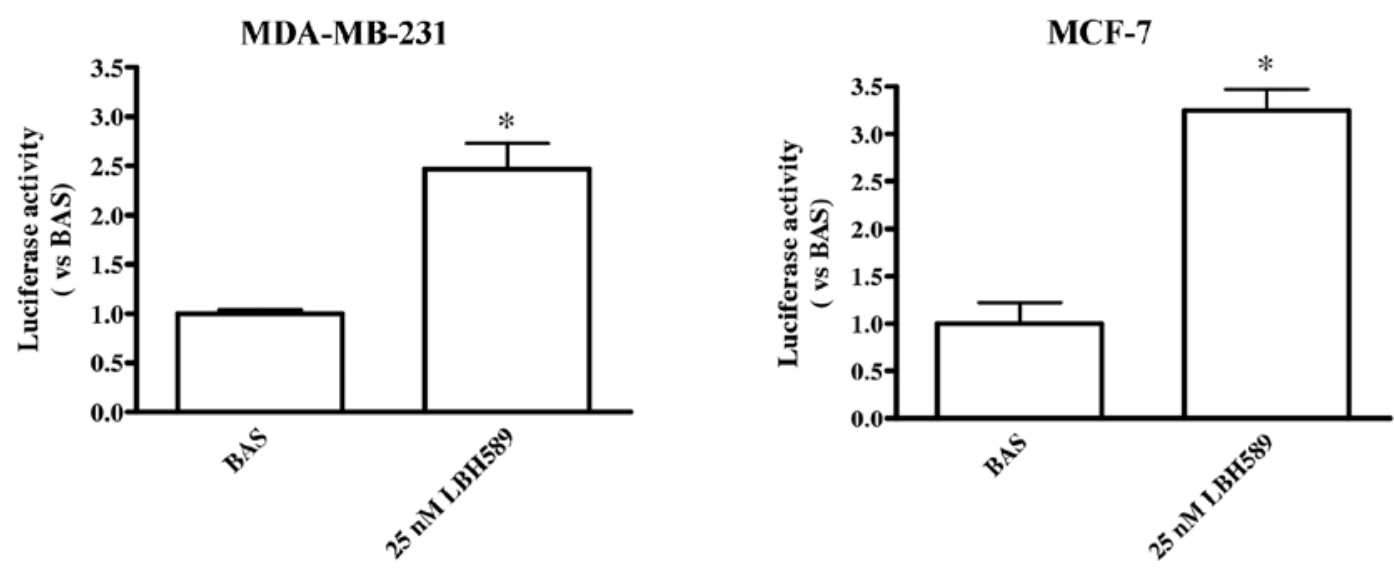

Figure 6. Effect of LBH589 on CDH1 promoter activity. MDA-MB-231 and MCF-7 cells were transiently transfected with a reporter plasmid carrying the luciferase gene under the control of the $C D H 1$ promoter. The luciferase activity was assayed before and after treatment with $25 \mathrm{nM}$ LBH589. Data are expressed as the mean $\pm \mathrm{SD} ; \mathrm{n}=3 ;{ }^{*} \mathrm{P}<0.05$.

we report in the present study and consequent E-cadherin induction. Tate et al also noted an increase in the $\mathrm{CDHI}$ gene expression on the periphery of the primary tumour from MDA-MB-231 xenografts, and hypothesized that the induction of $\mathrm{CDH1}$ expression by LHB589 at the invasive edge may be indicative of decreased metastatic potential. Actually, our observation in vitro of reduced migration and invasion of MDA-MB-231 cells treated with LBH589 substantiates their hypothesis, confirming that E-cadherin induction by LBH589 has a functional meaning and could be exploited for therapeutic application.

It is also interesting to note that in ER-positive MCF-7 cells that express high level of E-cadherin, LBH589 is a clear antiproliferative and proapoptotic agent even at low nanomolar doses (16), but does not modify the E-cadherin expression and cell migration/invasion leaving unaffected the low metastatic potential of these cells.

As reported, in breast cancer MTA3/Snail/E-cadherin and estradiol (E2)/ER $\alpha$ signalling are closely linked (34). The appearance of E-cadherin in MDA-MB-231 cells treated with LBH589 could be due to the reactivation of ER $\alpha$ pathway in TNBC cells since other DCI were reported to act similarly in several studies. For example, DCI in association with demethylating agents like 5-aza-2'-deoxycytidine were shown to reactivate ER $\alpha$ expression in ER-negative breast cancer cells $(22,39,40)$; the DCI valproic acid was demonstrated to enhance the efficacy of the anti-estrogen tamoxifen through increasing ER-mediated transcription (16) and also to induce $\mathrm{ER} \alpha, \mathrm{PR}, \mathrm{pS} 2$ and FoxA1, giving to MDA-MB-231 cells an estrogen-sensitive 'phenotype' and restoring their sensitivity to anti-estrogen therapy (18).

Controversial results on LBH589 effect on ER $\alpha$ expression in MDA-MB-231 cells, either receptor induction (23) or no effect at all (24), have been reported.

The present data confirm that LBH589 does not induce $\mathrm{ER} \alpha$ expression and ER-pathway restoration in MDA-MB231 cells. Moreover, LBH589 reduced MTA3 levels, and significantly increased both Snail and Slug, whose levels are inversely related to E-cadherin expression, either in ER-negative MDA-MB-231 or in ER-positive MCF-7 cells.
Furthermore, in MCF-7 cells LBH589 significantly decreased the expression level of ER $\alpha$, PR and FoxA1, as previously reported (24). The effects of LBH589 on ER pathway are not consistent with those observed on E-cadherin gene and protein expression in both cell lines. It is thus conceivable that LBH589 can control E-cadherin independently of estradiol and this is not affected by the level of expression of Snail, in agreement with recent observations in ovarian carcinoma (41). Snail requires histone deacetylase activity to repress E-cadherin promoter and it has already been demonstrated that treatment with trichostatin A is sufficient to block this effect (42). Our data suggest that LBH589 in MDA-MB-231 breast cancer acts directly on the $\mathrm{CDH} 1$ promoter and does not need to modify E-cadherin transcriptional repressors to induce E-cadherin expression and to modify the cell aggressive attitude. In MCF-7 cells, even though LBH589 smoothens down the ER pathway, reducing MTA3 and increasing Snail and Slug, its direct action on $\mathrm{CDH1}$ promoter is also present, the final effect on E-cadherin protein expression is irrelevant, so that migration and invasion of MCF-7 cells are not affected.

In conclusion, LBH589 is able to induce E-cadherin in highly aggressive TNBC cells reducing their migration and invasion, by-passing E-cadherin transcriptional repressors such as Snail and Slug and without any detectable effect on ER $\alpha$ expression and pathway. This compound can, therefore, be proposed for treatment of aggressive breast cancer, refractory to hormonal therapy exploiting its antiproliferative and anti-invasive properties. At least eight different trials on advanced breast cancer treatment with LBH589 both in monotherapy and in association with trastuzumab, capecitabine, lapatinib, or paclitaxel, respectively, are now listed on the site www.clinicaltrials.gov. We are looking forward to their conclusions and strongly hope LBH589 will be available soon for advanced breast cancer treatment.

\section{Acknowledgements}

We thank Novartis Pharma AG, Basel, Switzerland for providing us with LBH589; and Daniela Taverna and 
Francesca Orso, Dipartimento di Biotecnologie Molecolari e Scienze della Salute, Università di Torino and M.B.C., Torino, Italy, for helping us with luciferase experiments.

\section{References}

1. Parkin DM, Bray F, Ferlay J and Pisani P: Global cancer statistics, 2002. CA Cancer J Clin 55: 74-108, 2005.

2. Berry DA, Cronin KA, Plevritis SK, Fryback DG, Clarke L, Zelen M, Mandelblatt JS, Yakovlev AY, Habbema JD and Feuer EJ: Cancer Intervention and Surveillance Modeling Network (CISNET) Collaborators. Effect of screening and adjuvant therapy on mortality from breast cancer. N Engl J Med 353: 1784-1792, 2005

3. Cardoso F, Bedard PL, Winer EP, Pagani O, Senkus-Konefka E, Fallowfield LJ, Kyriakides S, Costa A, Cufer T and Albain KS: ESO-MBC Task Force, International guidelines for management of metastatic breast cancer: combination vs. sequential single-agent chemotherapy. J Natl Cancer Inst 101: 1174-1181, 2009.

4. Gonzalez-Angulo AM, Morales-Vasquez F and Hortobagyi GN: Overview of resistance to systemic therapy in patients with breas cancer. Adv Exp Med Biol 608: 1-22, 2007.

5. Dent R, Trudeau M, Pritchard KI, Hanna WM, Kahn HK, Sawka CA, Lickley LA, Rawlinson E, Sun P and Narod SA: Triple-negative breast cancer: clinical features and patterns of recurrence. Clin Cancer Res 13: 4429-4434, 2007.

6. Schneider BP, Winer EP, Foulkes WD, Garber J, Perou CM Richardson A, Sledge GW and Carey LA: Triple-negative breast cancer: risk factors to potential targets. Clin Cancer Res 14 8010-8018, 2008.

7. Anders CK and Carey LA: Biology, metastatic patterns, and treatment of patients with triple-negative breast cancer. Clin Cancer Res 9: S73-S81, 2009.

8. Elias AD: Triple-negative breast cancer: a short review. Am J Clin Oncol 33: 637-645, 2010.

9. Rodríguez-Paredes M and Manel Esteller M: Cancer epigenetic reaches mainstream oncology. Nat Med 17: 330-339, 2011.

10. Sawan C, Vaissière T, Murr R and Herceg Z: Epigenetic drivers and genetic passengers on the road to cancer. Mutat Res 642 $1-13,2008$

11. Ellis L, Atadja PW and Johnstone RW: Epigenetics in cancer: targeting chromatin modifications. Mol Cancer Ther 8: 1409-1420, 2009.

12. Wong ST: Emerging treatment combinations: integrating therapy into clinical practice. Am J Health Syst Pharm 66 : S9-S14, 2009.

13. Göttlicher M, Minucci S, Zhu P, Krämer OH, Schimpf A, Giavara S, Sleeman JP, Lo Coco F, Nervi C, Pelicci PG and Heinzel T: Valproic acid defines a novel class of HDAC inhibitors inducing differentiation of transformed cells. EMBO J 20: 6969-6978, 2001.

14. Hodges-Gallagher L, Valentine CD, Bader SE and Kushner PJ: Inhibition of histone deacetylase enhances the anti-proliferative action of antiestrogens on breast cancer cells and blocks tamoxifen-induced proliferation of uterine cells. Breast Cancer Res Treat 105: 297-309, 2007.

15. Fortunati N, Bertino S, Costantino L, Bosco O, Vercellinatto I, Catalano MG and Boccuzzi G: Valproic acid is a selective antiproliferative agent in estrogen-sensitive breast cancer cells. Cancer Lett 259: 156-164, 2008.

16. Fortunati N, Catalano MG, Marano F, Mugoni V, Pugliese M, Bosco O, Mainini F and Boccuzzi G: The pan-DAC inhibitor LBH589 is a multi-functional agent in breast cancer cells: cytotoxic drug and inducer of sodium-iodide symporter (NIS). Breast Cancer Res Treat 124: 667-675, 2010.

17. Hajra KM, Ji X and Fearon ER: Extinction of E-cadherin expression in breast cancer via a dominant repression pathway acting on proximal promoter elements. Oncogene 18: 7274-7279, 1999.

18. Fortunati N, Bertino S, Costantino L, De Bortoli $M$, Compagnone A, Bandino A, Catalano MG and Boccuzzi G: Valproic acid restores ER alpha and antiestrogen sensitivity to ER alpha-negative breast cancer cells. Mol Cell Endocrinol 314: $17-22,2010$

19. Katzenellenbogen BS and Frasor J: Therapeutic targeting in the estrogen receptor hormonal pathway. Semin Oncol 31: 28-38, 2004.
20. Ring A and Dowsett M: Mechanisms of tamoxifen resistance. Endocr Relat Cancer 11: 643-658, 2004.

21. Jovanovic J, Rønneberg JA, Tost J and Kristensen V: The epigenetics of breast cancer. Mol Oncol 4: 242-254, 2010.

22. Zhou Q, Atadja P and Davidson NE: Histone deacetylase inhibitor LBH589 reactivates silenced estrogen receptor alpha (ER) gene expression without loss of DNA hypermethylation. Cancer Biol Ther 6: 64-69, 2007.

23. Fiskus W, Ren Y, Mohapatra A, Bali P, Mandawat A, Rao R, Herger B, Yang Y, Atadja P, Wu J and Bhalla K: Hydroxamic acid analogue histone deacetylase inhibitors attenuate estrogen receptor-alpha levels and transcriptional activity: a result of hyperacetylation and inhibition of chaperone function of heat shock protein 90. Clin Cancer Res 13: 4882-4890, 2007.

24. Hayashi A, Horiuchi A, Kikuchi N, Hayashi T, Fuseya C, Suzuki A, Konishi I and Shiozawa T: Type-specific roles of histone deacetylase (HDAC) overexpression in ovarian carcinoma: HDAC1 enhances cell proliferation and HDAC3 stimulates cell migration with downregulation of E-cadherin. Int J Cancer 127: 1332-1346, 2010.

25. Thiery JP, Acloque H, Huang RY and Nieto MA: Epithelialmesenchymal transitions in development and disease. Cell 139: 871-890, 2009

26. Lombaerts M, van Wezel T, Philippo K, Dierssen JWF, Zimmerman RME, Oosting J, van Eijk R, Eilers PH, van De Water B, Cornelisse CJ and Cleton-Jansen AM: E-cadherin transcriptional downregulation by promoter methylation but not mutation is related to epithelial-to-mesenchymal transition in breast cancer cell lines. Br J Cancer 94: 661-671, 2006.

27. Nam JS, Ino Y, Kanai Y, Sakamoto $M$ and Hirohashi S: 5-Aza-2'-deoxycytidine restores the E-cadherin system in Ecadherin-silenced cancer cells and reduces cancer metastasis. Clin Exp Metastasis 21: 49-56, 2004.

28. Blanco MJ, Moreno-Bueno G, Sarrio D, Locascio A, Cano A, Palacios J and Nieto MA: Correlation of Snail expression with histological grade and lymph node status in breast carcinomas. Oncogene 21: 3241-3246, 2002.

29. Cheng CW, Wu PE, Yu JC, Huang CS, Yue CT, Wu CW and Shen CY: Mechanisms of inactivation of E-cadherin in breast carcinoma: modification of the two-hit hypothesis of tumor suppressor gene. Oncogene 20: 3814-3823, 2001.

30. Elloul S, Elstrand MB, Nesland JM, Trope CG, Kvalheim G, Goldberg I, Reich R and Davidson B: Snail, Slug, and Smad-interacting protein 1 as novel parameters of disease aggressiveness in metastatic ovarian and breast carcinoma. Cancer 103: 1631-1643, 2005.

31. Rosivatz E, Becker I, Specht K, Fricke E, Luber B, Busch R, Hofler $\mathrm{H}$ and Becker KF: Differential expression of the epithelialmesenchymal transition regulators Snail, SIP1, and Twist in gastric cancer. Am J Pathol 161: 1881-1891, 2002.

32. Yang J, Mani SA, Donaher JL, Ramaswamy S, Itzykson RA, Come C, Savagner P, Gitelman I, Richardson A and Weinberg RA: Twist, a master regulator of morphogenesis, plays an essential role in tumor metastasis. Cell 117: 927-939, 2004.

33. Fearon ER: Connecting estrogen receptor function, transcriptional repression, and E-cadherin expression in breast cancer. Cancer Cell 3: 307-310, 2003.

34. Fujita N, Jaye DL, Kajita M, Geigerman C, Moreno CS and Wade PA: MTA3, a Mi-2/NuRD complex subunit, regulates an invasive growth pathway in breast cancer. Cell 113: 207-219, 2003.

35. Catalano MG, Pugliese M, Gargantini E, Grange C, Bussolati B, Asioli S, Bosco O, Poli R, Compagnone A, Bandino A, Mainini F, Fortunati $\mathrm{N}$ and Boccuzzi G: Cytotoxic activity of the histone deacetylase inhibitor Panobinostat (LBH589) in anaplastic thyroid cancer in vitro and in vivo. Int J Cancer 130: 694-704, 2012.

36. Maiso P, Carvajal-Vergara X, Ocio EM,López-Pérez R, Mateo G, Gutiérrez N, Atadja P, Pandiella A and San Miguel JF: The histone deacetylase inhibitor LBH589 is a potent antimyeloma agent that overcomes drug resistance. Cancer Res 66: 5781-5789, 2006.

37. Shao W, Growney JD, Feng Y, O'Connor G, Pu M, Zhu W, Yao YM, Kwon P, Fawell S and Atadja P: Activity of deacetylase inhibitor Panobinostat (LBH589) in cutaneous T-cell lymphoma models: defining molecular mechanisms of resistance. Int $\mathrm{J}$ Cancer 127: 2199-2208, 2010

38. Tate CR, Rhodes LV, Segar HC, Driver JL, Pounder FN, Burow ME and Collins-Burow BM: Targeting triple-negative breast cancer cells with the histone deacetylase inhibitor panobinostat. Breast Cancer Res 14: R79, 2012. 
39. Keen JC, Yan L, Mack KM, Pettit C, Smith D, Sharma D and Davidson NE: A novel histone deacetylase inhibitor, scriptaid, enhances expression of functional estrogen receptor alpha (ER) in ER negative human breast cancer cells in combination with 5-aza 2'-deoxycytidine. Breast Cancer Res Treat 81: 177-186, 2003.

40. Sharma D, Saxena NK, Davidson NE and Vertino PM Restoration of tamoxifen sensitivity in estrogen receptornegative breast cancer cells: tamoxifen-bound reactivated ER recruits distinctive corepressor complexes. Cancer Res 66: 6370-6378, 2006.
41. Peinado H, Ballestar E, Esteller M and Cano A: Snail mediates E-cadherin repression by the recruitment of the Sin3A/histone deacetylase 1 (HDAC1)/HDAC2 complex. Mol Cell Biol 24: 306-319, 2004.

42. Kim IA, No M, Lee JM, Shin JH, Oh JS, Choi EJ, Kim IH, Atadja $\mathrm{P}$ and Bernhard EJ: Epigenetic modulation of radiation response in human cancer cells with activated EGFR or HER-2 signaling: potential role of histone deacetylase 6 . Radiother Oncol 92: 125-132, 2009. 